\title{
Assessment of Culturable Microbial Diversity Associated with Arnebia euchroma: A Critically Endangered Plant Growing in Trans-Himalayas of Himachal Pradesh, India
}

\author{
Sunita Devi* and Kirti Kaundal \\ Department of Basic Sciences, Dr. Y.S. Parmar University of Horticulture and Forestry, \\ Nauni- Solan (H.P) -173230, India \\ *Corresponding author
}

\begin{tabular}{|c|c|}
\hline & A B S T R A C T \\
\hline $\begin{array}{l}\text { Arnebia euchroma, } \\
\text { Microbial diversity, } \\
\text { Shannon - Wiener } \\
\text { index, Microbial } \\
\text { load, Medicinal } \\
\text { plants, Trans - } \\
\text { Himalaya. }\end{array}$ & \multirow{3}{*}{$\begin{array}{l}\text { This paper presents a pioneer study on the microbial diversity associated with the } \\
\text { rhizosphere of Arnebia euchroma, considering the medicinal importance and critically } \\
\text { endangered status of this taxon. Rhizospheric soil samples of Arnebia euchroma were } \\
\text { collected from two villages namely Nako and Chango in Kinnaur and one i.e. Gue in } \\
\text { Lahaul \& Spiti district of Himachal Pradesh. Chemical profile of soils revealed pH value } \\
\text { in alkaline range of } 7.97 \text { to } 8.43 \text {. The organic carbon content varied from } 0.60 \text { to } 1.20 \% \text {. } \\
\text { The available P and } \mathrm{N} \text { contents were very high and low, respectively. The available } \mathrm{K} \\
\text { content was high in Nako and Chango and medium in Gue. Zn and Mn contents were } \\
\text { found to be low whereas, Cu and Fe contents were comparatively high. A total of } 105 \\
\text { microbial isolates were obtained from all the samples. The bacterial and actinomycetes } \\
\text { loads were found to be significantly higher at Gue followed by Nako and Chango. High } \\
\left.\text { value of Shannon - Wiener index ( } \mathrm{H}^{\prime}\right) \text { was found at Gue as compared to Chango and Nako. } \\
\text { However, evenness (E1) values were comparatively low at Gue than Chango and Nako, } \\
\text { which implies that Gue has a greater diversity of microbial species, which however was } \\
\text { not evenly distributed. }\end{array}$} \\
\hline Artic & \\
\hline $\begin{array}{l}\text { Accepted: } \\
28 \text { Augus } \\
\text { Available } \\
10 \text { Septem }\end{array}$ & \\
\hline
\end{tabular}

\section{Introduction}

India, particularly the Trans-Himalayan region, is a varietal emporium of medicinal plants species and has been a major part of India's rich medicinal plant heritage (Alluri et al., 2005; Bhadrecha et al., 2017). This vast wealth is widely distributed in different parts of the country having specific phyto geographical entities. Medicinal plants are considered as the backbone of the traditional medicines being used worldwide. Owing to variations in altitude and topography, Himachal Pradesh, located in the lap of the Himalayas, has varied climatic conditions, which make this state ideal for the thriving of a wide diversity of medicinal plant species (Sharma and Mishra, 2009; Singh and Thakur, 2014). Consequently, the state is a bucket of large variety of medicinal herbs.

More than $50 \%$ medicinal plants traditionally used in India come from the Himalayan region (Uniyal et al., 2002; Verma and Tiwari, 2016). This biodiversity of medicinal plants and its sustainable utilization by the local people for various activities (traditional healthcare, cultural and religious) help in 
sustaining their health, medicinal, spiritual and other needs (Gautam et al., 2011).

Earlier, only the local people used these plants resources for their own consumption, but in the recent decades, the demand of herbal products and plant based drugs in national and international markets has increased rapidly (Tandon, 2001;Sharma, 1998) leading to the heavy exploitation of medicinal plants. One of the prime reasons for their over exploitation is the dependence of such a huge population of human beings on these valuable and limited resource based in nature. Additionally, traditional practices of livestock grazing, harvesting of commercially important species and demand for fuel wood and fodder are the major anthropogenic activities prevalent throughout the NorthWestern Himalayas that has resulted in the selective removal of highly valuable species from many of their sectors.

The problems are compounded by marketdemand driven unscientific harvesting of these medicinal plants without any concern for representation and conservation. In the process, essential regenerative components of a plant like roots, tubers, fruits, seeds, flowers and bark are indiscriminately collected, leading to degradation, depletion and even extinction of particular species. Due to this ruthless exploitation, many important medicinal plants species are becoming rare and some of them are critically endangered (Pandey et al., 2005). Arnebia euchroma represents a classical example of a critically endangered plant that is found in the trans- Himalayas of Himachal Pradesh, though mainly harvested for its roots; almost all parts of the plant are being used in medicines, food, dyes and beverages.

Arnebia euchroma belongs to family Boraginaceae, commonly known as
'Ratanjot'. It is a well- known traditional perennial, erect, caespitoseand hairy herb with many stems arising from the axils of its basal leaves, distributed in dry regions of Asia and Northern Africa (Liu et al., 2012). The plant grows in well-drained sandy soil but can also grow in nutritionally poor soil. It cannot grow in shade. Its reproductive cycle ranges from June to August. Its roots are purple in colour and are used in many herbal medicine preparations. Out of total 5 species of genus Arnebia, only 3 are reported to be found in the Lahaul and Spiti region - the cold desert of trans-Himalayas (Aswal and Mehrotra, 1994). Out of these three species, Arnebia euchroma (syn. Macrotomia perennis Boiss) has been exploited commercially on a large scale. Known as Dimok or Khamed in native language, the species is famous by its trade name Ratanjot (Singh et al., 2012). During 1998, euchroma species was placed under the category of endangered plants (Vedand and Tandon, 1998). However, owing to medicinal properties, plants of A. euchroma have been overexploited and have, now been included in the list of critically endangered plant for Himachal Pradesh according to the latest IUCN categorization (Kala et al., 2004; Manjkhola et al., 2005; Singh et al., 2012).

All plant-associated microenvironments are colonized in high abundances by microorganisms, especially the nutrient-rich rhizosphere, the soil area influenced by plant roots, hosts a plethora of microbes that are of central importance for plant nutrition, health, and quality (Hiltner, 1904: Berg, 2009; Mendes et al., 2011, 2013). In response, plants play a significant role in shaping the rhizospheric microbial community through direct physical interaction, and by secreting various chemicals in the form of root exudates (Bednarek et al., 2010). The study of rhizospheric microorganisms associated with medicinal plants is very crucial, as they are well known to produce industrially important 
metabolites and improve quality of medicinal product besides their impact on plant growth (Bafana and Lohiya, 2013). A significant number of bacteria produce the phytotherapeutic compounds (Koeberl et al., 2013) and increase the growth of the medicinal plants when they are associated with rhizosphere of plants. The rhizospheric soil under the influence of plant roots (Hartmann, 2007) is considered one of the most diverse microbial habitats with respect to species richness and community size (Mendes et al., 2008). Diversity indices are used to characterize species abundance relationships in communities (Ludwig and Reynolds, 1988).

As such, there is no report on the number and composition of microorganisms present in the rhizosphere of Arnebia euchroma. Moreover, the herb under study grows in the transHimalayan region of Himachal Pradesh, which is a unique habitat for its growth, the microbial diversity present in its rhizosphere, may help in adaptation of plant under prevailing conditions. Therefore, the aim of the present study was to assess the microbial diversity associated with Arnebia euchroma.

\section{Materials and Methods}

\section{Description of study areas}

Extensive survey was done for locating Arnebia euchroma -a valuable medicinal plant, in two districts of Himachal Pradesh viz. Kinnaur and Lahaul \& Spiti. Kinnaur is located in the North-eastern part of Himachal Pradesh and it shares its eastern boundary with Tibet. Most of the areas in Kinnaur have a temperate climate due to its high elevation. The lower parts receive monsoon rains whereas the upper areas of Kinnaur fall in the rain shadow area. Lahaul\& Spiti is an integral part of Indian cold desert area of Northernwestern Himalayan region. Located in the alpine arid zone of Himachal Pradesh, it is comprised of two subdivisions - Lahaul \& Spiti. Despite the prevalence of extreme climatic conditions, Kinnaur and Lahaul Spiti areas harbor valuable medicinal plant wealth. Accordingly, two villages namely Nako and Chango in Kinnaur and one i.e Gue in Lahaul and Spiti district were selected for the collection of rhizospheric soil samples of Arnebia euchroma (Figure 1).

\section{Collection of samples}

Three rhizospheric soil samples were collected in plastic bags, separately from each of the selected village from a depth of $1 \frac{1 / 2}{2}-2$ feet, about $10 \mathrm{~cm}$ apart and were mixed together to make one composite soil sample. The plant was found to be in vegetative phase at Nako, flowering stage at Chango and preflowering stage at Gue site (Fig. 2).

\section{Chemical profile of soil samples}

The soil samples collected from different locations were analyzed for different soil chemical properties by employing following standard methods given below in the Table 1.

\section{Determination of microbial load in rhizospheric soil samples}

Standard plate count technique was employed for determining the microbial load the rhizospheric soil samples.

\section{Standard plate count technique}

Rhizospheric soil samples were serially diluted to 10 folds by transferring one $\mathrm{mL}$ of sample to $9 \mathrm{~mL}$ sterile dilution blank under aseptic conditions. The microbial load present in all the samples was determined by plating serial dilutions of samples (Wollum, 1982) on nutrient agar (NA), potato dextrose agar (PDA) and Kenknight medium, separately 
with three replicates every time, for the isolation of bacteria, fungi and actinomycetes, respectively. The NA plates were incubated at $28 \pm 2{ }^{\circ} \mathrm{C} ; 37 \pm 2{ }^{\circ} \mathrm{C}$ and $4{ }^{\circ} \mathrm{C}$ for $24-48 \mathrm{~h}$, PDA plates at $28 \pm 2{ }^{\circ} \mathrm{C}$ for $2-5$ days while Kenknight medium plates at $28 \pm 2{ }^{\circ} \mathrm{C}$ and 37 $\pm 2{ }^{\circ} \mathrm{C}$ for $7-11$ days. Microbial counts of processed samples were recorded and expressed in terms of $\log \mathrm{CFU} \mathrm{mL} \mathrm{m}^{-1}$.

\section{Elucidation of microbial diversity}

To elucidate the microbial diversity present in the rhizospheric soil samples, different morphotypes of bacteria, fungi and actinomycetes obtained on nutrient agar, potato dextrose agar and Kenknight media, respectively were selected on the basis of their morphological characteristics and purified on their respective media.

\section{Quantitative analysis of microbial diversity}

For studying population dynamics of microbes in the soil samples collected from different locations, diversity indices were calculated using the following formulae (Ventorino et al., 2007).

\section{Margalef's index for richness (R)}

$\mathrm{R}=\frac{\mathrm{S}-1}{\operatorname{In} \mathrm{N}}$

Where, $\mathrm{S}=$ Number of Bacteria; $\mathrm{N}=$ Total number of microbial isolates obtained

\section{Shannon- Wiener index of diversity $\left(\mathrm{H}^{\prime}\right)$}

$\mathrm{H}=\Sigma \mathrm{P}_{\mathrm{i}} \ln \mathrm{P}_{\mathrm{i}}$

Where, $\mathrm{P}_{\mathrm{i}}$ is the relative abundance of bacterial/fungal/actinomycetes isolates calculated according to the following equation:
$\mathrm{Pi}=\frac{\text { ni }}{\mathrm{N}}$

Where, $n_{i}$ denotes the number of bacterial/fungal/actinomycetes isolates and $\mathrm{N}$ denotes the total number of microbial isolates obtained.

\section{Simpson's index of dominance (D)}

$\mathrm{D}=\Sigma \mathrm{P}_{\mathrm{i}}^{2}$

$\mathrm{P}_{\mathrm{i}}$ is calculated as given in Shannon- Wiener index of diversity $\left(\mathrm{H}^{\prime}\right)$

Evenness index (E1)

E1 = $\frac{H^{\prime}}{-[\ln S]}$

Where, $\mathrm{S}=$ Number of Bacteria; $\mathrm{H}^{\prime}=$ Shannon- Wiener diversity index

\section{Statistical analysis}

All the experiments were performed in triplicates and results were statistically analyzed using statistical software OP STAT.

\section{Results and Discussion}

Trans- Himalayas of Himachal Pradesh harbor a number of medicinal plants that are under various categories of threats due to heavy extraction. Several years of overexploitation and unscientific harvesting of valuable medicinal plants in this region have resulted in depletion of their population densities (Kala, 2000; Dhyani and Kala, 2005) and as such, conservation of plant biodiversity in this region has become a major concern. Arnebia euchroma faces similar threats, as it is a usual practice in this region to sell and use its roots as edible dye and 
medicine (Aswal and Mehrotra, 1994; Singh et al., 2012).We focused our study on assessing the culturable microbial diversity associated with this valuable medicinal plant that may directly or indirectly help in its adaptation under prevailing conditions by improving its growth, nutrient availability, disease resistance, yield and quality of medicinal compounds.

The rhizosphere can persist for years depending on whether a plant is an annual or a perennial. Even when a root dies, it will continue to support a succession of organisms and speeds nutrient cycling besides increasing the availability of nutrients for plant uptake. The microbial diversity and community structures are greatly affected by biotic and abiotic factors in a particular environment (Finlay, 2002; Madigan et al., 2008; Griffiths et al., 2011). Soil physico-chemical properties are the most important among these factors that determine the nutrient supplying power of the soil to the plants and microbes as well as affect plant and microbial physiology and thus bacterial rhizosphere populations (Hinsinger et al., 2009; Saharan and Nehra, 2011; Philippot et al., 2013).

\section{Chemical profile of soil samples}

Chemical properties of all rhizospheric soil samples collected from selected locations were determined and results are depicted in Table 1, which reveals that the $\mathrm{pH}$ of soil samples varied from 7.97 to 8.43 , being lowest at Nako and highest at Gue. The electrical conductivity values ranged from $0.109-0.222 \mathrm{dS} \mathrm{m}^{-1}$. The organic carbon content was observed to be in the medium range at all the locations, varying from 0.60 to $1.20 \%$. The available phosphorus (P) and nitrogen $(\mathrm{N})$ contents in soils were observed to be very high and low, respectively, in all soil samples. Similarly, the available potassium (K) content was high in soil samples collected from Kinnaur whereas it was in the medium range in the soils of Gue (Spiti valley). As far as the micronutrients $(\mathrm{Cu}, \mathrm{Fe}, \mathrm{Mn}$ and $\mathrm{Zn}$ ) are concerned, $\mathrm{Zn}$ and Mn contents were observed to be low while, $\mathrm{Cu}$ and $\mathrm{Fe}$ contents are higher in all the soil samplesas compared to critical limits for available micronutrients. It is imperative to note that Arnebia euchroma prefers alkaline soil with medium range of micro and macronutrients for its natural growth, development and distribution.

Relatively alkaline soil $\mathrm{pH}$ values of all the rhizospheric soil samples under study ranged from 7.97- 8.43 might be attributed to higher accumulation of $\mathrm{CaCO}_{3}$ and other salts due to extremely low rainfall and high evaporation rate in these areas. Sharma and Kanwar, (2010) reported that the soils of Spiti valley on an average, had the highest $\mathrm{pH}$ value (8.0) followed by soils of Kinnaur valley (7.9) and lowest in Udaipur valley (6.9). The $\mathrm{pH}$ values obtained in these valleys were in accordance with the findings of Parmar et al., (1999); Raina et al., (2003) and Singh et al., (2012).

The electrical conductivity has generally been associated with soil salinity, which was found to be an important determinant of microbial community composition (Lozupone and Knight, 2007). Salt stress was found to increase the diversity of rhizosphere bacterial communities in the rhizosphere of halophyte plants (Yang et al., 2016).The electrical conductivity values of soils under study reveals that soils are low in soluble salts concentration with EC values ranged from 0.109 to $0.222 \mathrm{dScm}^{-1}$ which might be attributed to slow microbial activities under prevailing low temperature conditions. Considering the organic carbon content $<0.5$ $\%$ as low, $0.5-1.0$ per cent medium and $>1 \%$ high, respectively, the tested soil samples fall under medium and high organic carbon content category, with medium organic 
carbon contents both at Chango (0.75) and

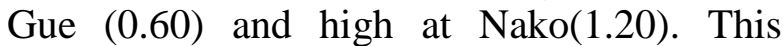
could probably be due to the prevalence of low temperature over a long period of time in these areas which depressed the process of decomposition of organic matter due to low microorganisms' activities in these soils (Sharma and Kanwar, 2010). Low to high content of organic carbon is also attributed to the variation in decomposition rate (Yadav and Meena, 2009).

Despite medium to high organic content of the soils, the available nitrogen in all the soil samples was low, which might be attributed to low rate of decomposition of organic carbon and negligible use of the chemical fertilizers. Our results are in harmony with the results of Sharma and Kanwar, (2012), who observed $73 \%$ nitrogen deficiency in the soils of Gondhla valley followed by Kinnaur (48 $\%)$, Spiti (46\%), Pattan valley (43\%) and Udaipur valley $(28 \%)$.

The higher range of the available phosphorus (P) in all the soils of this zone could be ascribed to inorganic sources of $\mathrm{P}$ from mineral weathering which have considerable importance in their contribution to soil available $\mathrm{P}$ as intensified human practices increase the rate of weathering and encourage decomposition (Bewket and Steroosnijder, 2003). According to Sharma and Kanwar (2012), the availability of phosphorus in soil is highly $\mathrm{pH}$ dependent with maximum availability near neutral soil $\mathrm{pH}$, which corroborated the higher content of available phosphorus in the soils of dry temperate zone of Himachal Pradesh.

The medium to higher range of the available potassium in the soils of this zone is due to the presence of feldspar and quartz as the sedentary parent material (Verma, 1979), which are the rich source of the potassium. Sharma and Kanwar (2012) reported similar observations for available potassium contents in the soils of dry temperate zone of Himachal Pradesh. The micronutrients viz. $\mathrm{Zn}$ and $\mathrm{Mn}$ contents were observed to be low while, $\mathrm{Cu}$ and $\mathrm{Fe}$ contents were higher in all the soil samples as compared to their critical limits.

This could be attributed to the fact that physico- chemical properties of soil viz. $\mathrm{pH}$, organic $\mathrm{C}$, texture, and $\mathrm{CaCO}_{3}$ appreciably regulated the available status of micronutrients in all the soils.

\section{Determination of microbial load}

The rhizosphere of medicinal plants harbors a distinctive plethora of microbes due to their unique and structurally divergent bioactive secondary metabolites that are most likely responsible for the high specificity of the associated microorganisms (Qi et al., 2012). Although, higher density of microbes in the rhizosphere has been reported in many plants (Nannipieri et al., 2007; Joshi and Bhatt, 2011; Timmusk et al., 2011; Berendsen et al., 2012; Rout and Southworth, 2013; Gaiero et al., 2013), there are no reports on the number and composition of microbial communities associated with critically endangered medicinal plant Arnebia euchroma.

The data depicted in Table 2 revealed a statistically significant difference was observed in the microbial load among three locations (Nako, Chango and Gue). The bacterial and actinomycetes loads were found to be significantly higher (7.02 $\log \mathrm{CFU} / \mathrm{mL}$; $4.49 \log \mathrm{CFU} / \mathrm{mL}$, respectively) at Gue followed by Nako (6.72 $\log \mathrm{CFU} / \mathrm{mL} ; 4.15$ $\log \mathrm{CFU} / \mathrm{mL}$, respectively) and Chango (6.39 $\log \mathrm{CFU} / \mathrm{mL} ; \quad 4.04 \quad \log \mathrm{CFU} / \mathrm{mL}$, respectively). However, fungal load was observed to be higher at Gue (2.98 log $\mathrm{CFU} / \mathrm{mL}$ ) while, statistically at par in Nako (1.85 log CFU/mL) and Chango (1.77 log $\mathrm{CFU} / \mathrm{mL})$. 
Table.1 Methods employedfor estimating different soil chemical properties

\begin{tabular}{|c|l|l|}
\hline Particular & Method employed & Reference (s) \\
\hline pH & $\begin{array}{l}1: 2.5 \text { soil: water suspension, with the help } \\
\text { of digital pH meter }\end{array}$ & Jackson, (1967) \\
\hline EC & $\begin{array}{l}1: 2.5 \text { soil: water suspension, with the help } \\
\text { of digital EC meter }\end{array}$ & Jackson, (1967) \\
\hline Organic carbon & Rapid titration method & Walkley and Black, (1934) \\
\hline Available N & Alkaline potassium permanganate method & Subbiah and Asija, (1956) \\
\hline Available P & Olsen's method & Olsen et al., (1954) \\
\hline Available K & Ammonium acetate method & Merwin and Peech, (1951) \\
\hline $\begin{array}{l}\text { DiethyleneTriaminePenta } \\
\text { Acetic Acid DTPA) extractable } \\
\text { Zn, Fe, Mn and Cu }\end{array}$ & $\begin{array}{l}\text { Atomic Absorption Spectrophotometer } \\
\text { (AAS) }\end{array}$ & Lindsay and Norvell, (1978) \\
\hline
\end{tabular}

Table.2 Chemical properties of soil

\begin{tabular}{|c|c|c|c|c|c|c|c|c|c|c|c|}
\hline $\begin{array}{l}\text { Sr. } \\
\text { no }\end{array}$ & Location & $\mathbf{p H}$ & $\begin{array}{l}\text { EC } \\
\left(d S ~ m^{-1}\right)\end{array}$ & $\begin{array}{l}\text { Organic } \\
\text { Carbon }(\%)\end{array}$ & \multicolumn{3}{|c|}{$\begin{array}{c}\text { Available Macronutrients } \\
\left(\mathrm{kg} \mathrm{ha}^{-1}\right)\end{array}$} & \multicolumn{4}{|c|}{$\begin{array}{c}\text { Micronutrients } \\
(\mathrm{mg} / \mathrm{kg})\end{array}$} \\
\hline & & & & & $\mathbf{N}$ & $\mathbf{P}$ & $\mathbf{K}$ & $\mathbf{C u}$ & $\mathbf{F e}$ & Mn & $\mathbf{Z n}$ \\
\hline 1. & Nako & 7.97 & 0.222 & 1.20 & 125.4 & 89.6 & 417.7 & 6.00 & 10.70 & 10.86 & 0.91 \\
\hline 2. & Chango & 8.16 & 0.109 & 0.75 & 131.7 & 44.8 & 324.8 & 2.93 & 19.35 & 8.13 & 0.82 \\
\hline 3. & Gue & 8.43 & 0.112 & 0.60 & 137.9 & 67.2 & 120.9 & 1.74 & 7.45 & 11.11 & 0.78 \\
\hline
\end{tabular}

Table.3 Difference in microbial load present in the rhizosphere of Arnebia euchroma among three locations

\begin{tabular}{|c|c|c|c|}
\hline \multicolumn{4}{|c|}{ Microbial load (log CFU/mL) } \\
\hline Location & Bacteria & Fungi & Actinomycetes \\
\hline Nako & 6.72 & 1.85 & 4.15 \\
\hline Chango & 6.39 & 1.77 & 4.04 \\
\hline Gue & 7.02 & 2.98 & 4.49 \\
\hline $\mathrm{CD}_{0.05}$ & 0.015 & 0.244 & 0.075 \\
\hline
\end{tabular}

Table.4 Total number of isolates obtained from rhizospheric soil samples Collected from different locations

\begin{tabular}{|c|c|c|c|}
\hline Location & Type of microorganisms & Total no. of isolates & Grand total \\
\hline \multirow{3}{*}{ Nako } & Bacteria & 10 & \multirow{3}{*}{26} \\
\hline & Fungi & 4 & \\
\hline & Actinomycetes & 12 & \\
\hline \multirow{3}{*}{ Chango } & Bacteria & 17 & \multirow{3}{*}{31} \\
\hline & Fungi & 5 & \\
\hline & Actinomycetes & 9 & \\
\hline \multirow{3}{*}{ Gue } & Bacteria & 26 & \multirow{3}{*}{48} \\
\hline & Fungi & 9 & \\
\hline & Actinomycetes & 13 & \\
\hline \multicolumn{2}{|r|}{ Total } & 105 & 105 \\
\hline
\end{tabular}


Table.5 Comparison of microbial populations based on diversity Indices in the rhizosphere of Arnebia euchroma among three locations

\begin{tabular}{|c|c|c|c|c|}
\hline Location & $\begin{array}{c}\text { Margalef's } \\
\text { index for } \\
\text { richness } \\
\text { R=S-1/InN }\end{array}$ & $\begin{array}{c}\text { Shannon-Wiener } \\
\text { diversity index } \\
\text { (H') }\end{array}$ & $\begin{array}{c}\text { Simpson's index } \\
\text { of Dominance (D) }\end{array}$ & $\begin{array}{c}\text { Evenness } \\
\text { index (E1) } \\
\text { E1=H/InS }\end{array}$ \\
\hline Nako & 0.35 & 0.80 & 0.40 & 0.80 \\
\hline Chango & 1.13 & 0.91 & 0.46 & 0.74 \\
\hline Gue & 0.54 & 0.99 & 0.41 & 0.70 \\
\hline
\end{tabular}

Fig.1 Location map showing study areas along with sample collection sites

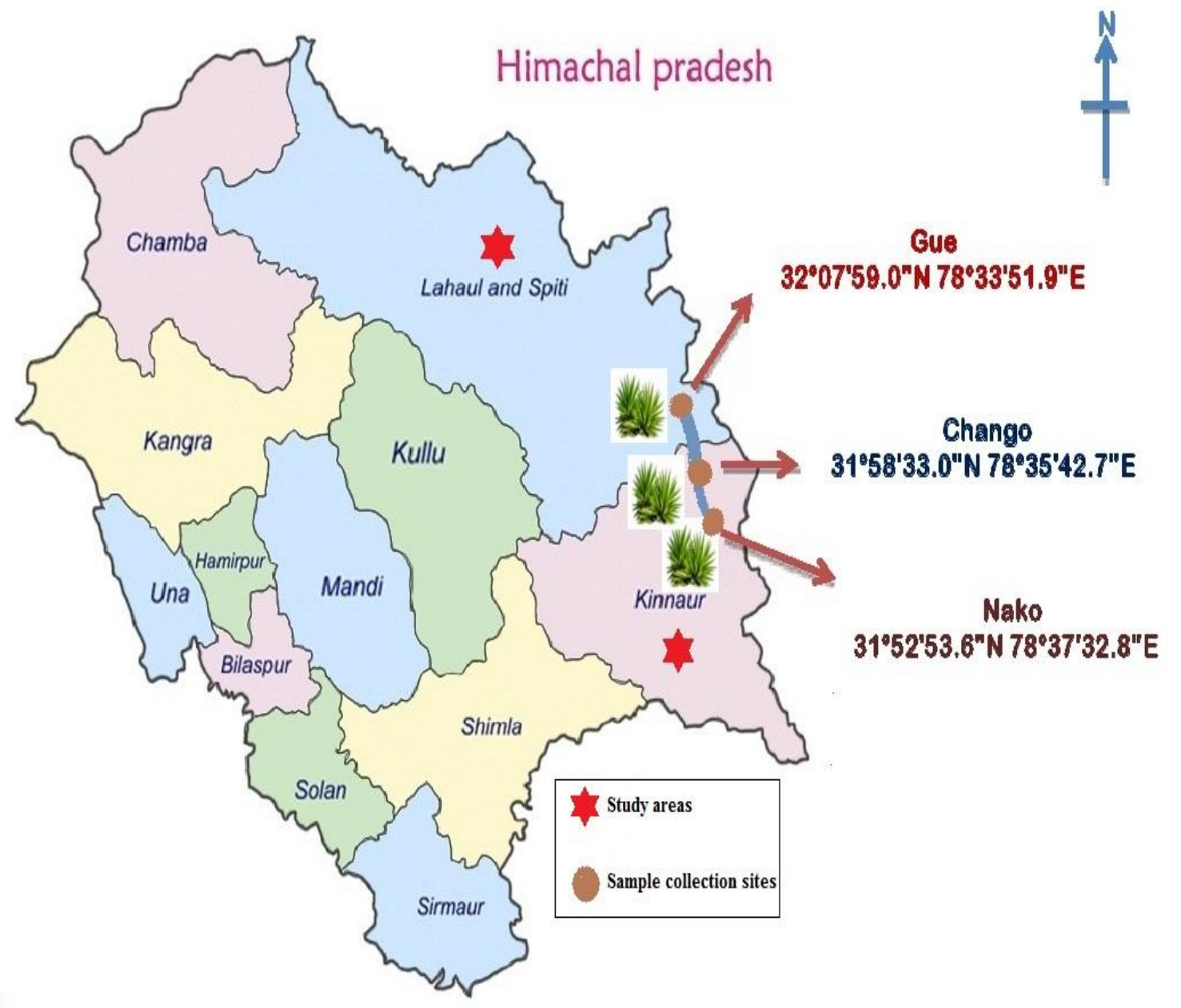


Fig.2 Showing Arnebia euchroma plants growing at different selected locations of Himachal Pradesh

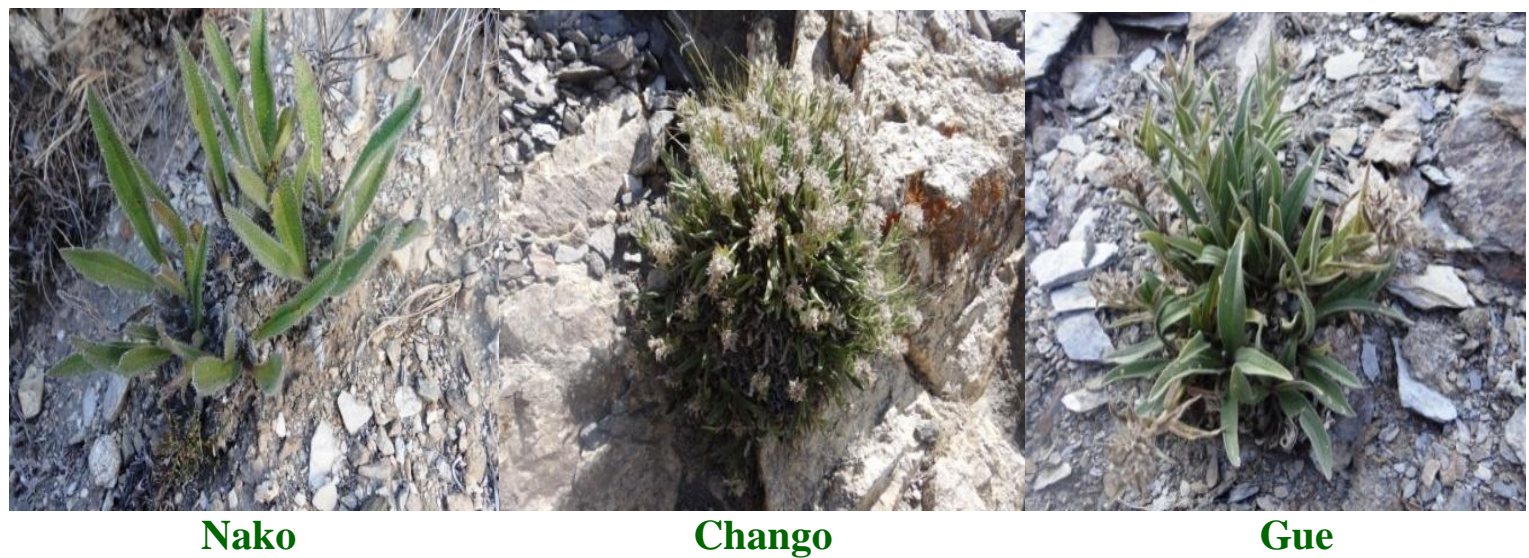

Fig.3 Showing the percentages of microbial isolates obtained from rhizospheric soil samples of Arnebia euchroma

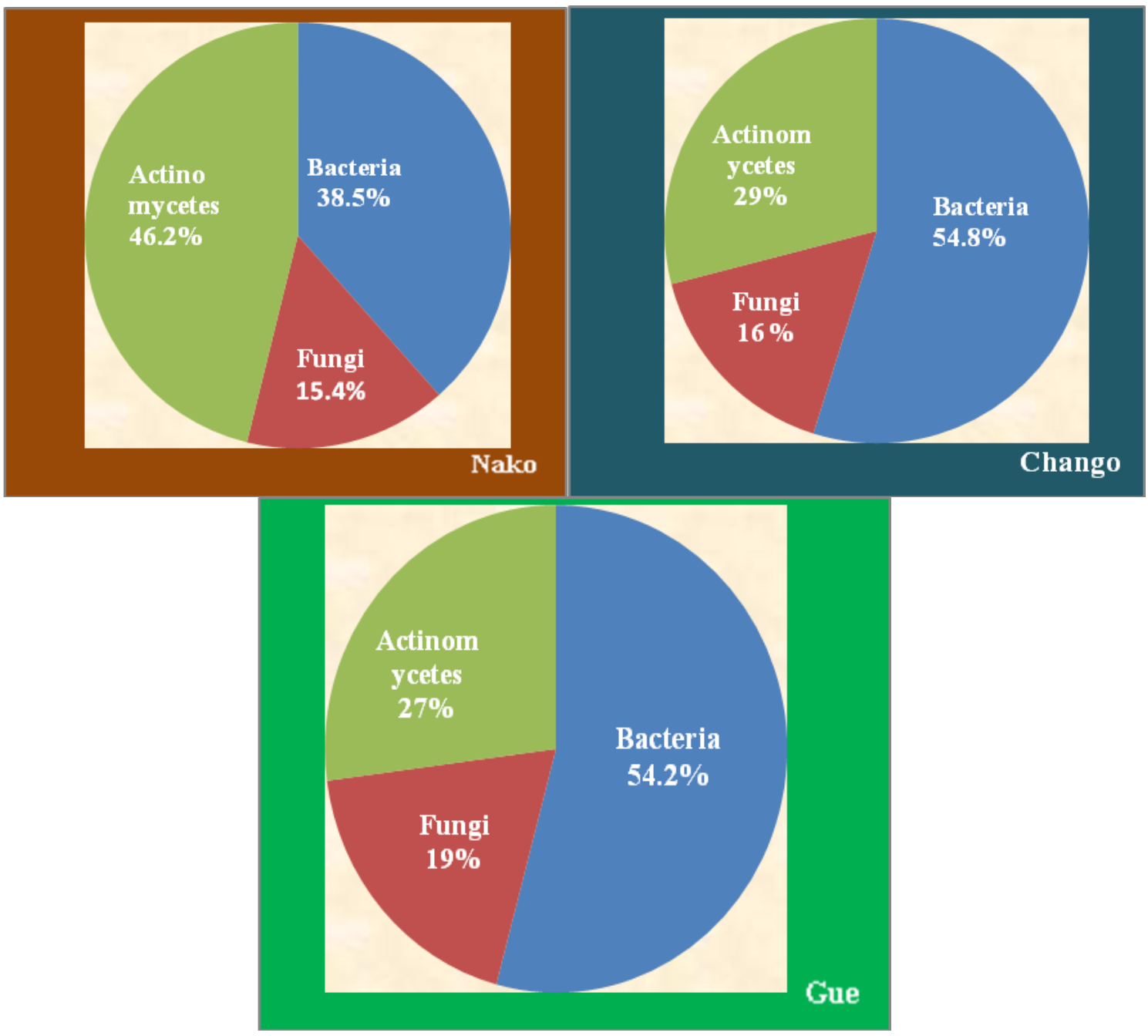


It is evident from these result that rhizosphere of Arnebia euchroma anchorages a quite high population density of bacteria, actinomycetes and fungi. Better nutrient availability in rhizosphere due to the deposition of various root exudates like sugars, amino acids, organic acids, aromatics, polysaccharides, proteins and various other secondary metabolites might be responsible for larger numbers of microbes in the rhizosphere. These results are strengthened by the study conducted by Karthikeyan et al., (2008) who reported high microbial load in the rhizosphere of four medicinal plants viz., Ocimum sanctum, Coleus forskholiiBriq, Catharanthusroseus and Aloe vera. Similar observations were reported by Yakoob et al., (2013) in the rhizosphere of Kochiaindica.

Further, the bacterial population density was found to be higher at all the locations followed by actinomycetes and fungi in the rhizosphere of the plant studied. This could be ascribed to the fact that bacteria feed on easily available carbon compounds while, fungi seem to prefer more complex carbon compounds as reported by Meidute et al., (2008). It is generally assumed that fungi live in soil as dormant propagules but areas under study falls in the cold temperate zone of the Himachal Pradesh where temperatures are extremely low that not only restrict microbial enzyme activity but also constrain the availability of liquid water for the hydration of these dormant propagules. (Russell, 1990; Crowe et al., 1992; Wynn-Williams and Edwards, 2000) also made same observations. However, the population of actinomycetes was higher than that of fungi because the former have the capability to metabolize diverse kind of complex compounds left after the decomposition of the organic substances, which are not generally attacked by other microorganisms to derive nutrition and energy (Hadar and Papadopoulou, 2012). Majority of actinomycetes are free-living organisms that are widely distributed in nature. These bacteria have high mechanisms of survival in adverse environment (Macagnan et al., 2006).

\section{Elucidation of microbial diversity}

Microbial diversity studies are important in order to understand the microbial ecology in soil and other ecosystems (Joshi et al., 2011). In total, 105 microbial isolates were obtained from all samples as depicted in the Table 3 based on differences in colony morphological features and purified. Maximum growth of bacteria and actinomycetes was observed at $28 \pm 2{ }^{\circ} \mathrm{C}$. Thus, it is evident from these results that it is the optimum temperature for the growth of these microorganisms. Morphological characterization revealed that most of the colonies were flat, transparent and raised; the color ranged from yellow to cream, and their margins were mainly entire and undulate. Among all the isolates, $79 \%$ per cent of the isolates were Gram positive, while $21 \%$ per cent were Gram negative.

The percentages of the bacterial population were observed to be almost same at Chango $(54.2 \%)$ and Gue $(54.8 \%)$, while comparatively low at Nako $(38.5 \%)$. Fungal population was highest at Gue (19\%) followed by Chango (16\%) and Nako $(15.4 \%)$, whereas, the percentage of actinomycetes isolates was recorded as highest at Nako (46.2\%) followed by Chango $(29 \%)$ and Gue $(27 \%)$ as shown in figure 3. Thus, it can be inferred from these results that the overall diversity observed in the rhizosphere of Arnebia euchroma reveals an abundance of bacteria followed by actinomycetes and fungi. This variation in microbial predominance observed in the rhizosphere of Arnebia euchroma could depends on the nutrients released by the plant in the rhizosphere micro-niche where decomposition of plant-derived carbon sources favor faster growing bacteria while 
disfavoring slower growing fungi and actinomycetes. Secondly, there may be some selective pressure exhibited by physicochemical characteristics of soils that permitted only selected types of organisms to thrive in the rhizosphere soil. These findings are in accordance with the reports of Fierer et al., (2007) and Lauber et al., (2009).

\section{Quantification assessment of microbial diversity}

Diversity, a multidimensional property of natural systems, is difficult to quantify partly because of the multitude of indices proposed for this purpose. Diversity Indices aim to describe general properties of communities that allow us to compare different regions, taxa, and trophic levels. Microorganisms are environment specific; therefore, for understanding the microbial diversity and their applications, investigation on occurrence of various groups of microorganisms from different environment is essential (Pandey et al., 2008).

The mathematical diversity indices viz., richness (R), Shannon-Wiener index ( $\left.\mathrm{H}^{\prime}\right)$, dominance (D) and evenness (E1) were used to study the diversity of various groups of microorganisms obtained from rhizosphere of Arnebia euchroma among three locations and results are depicted in Table 4 . The values of Shannon- Wiener diversity index $\left(\mathrm{H}^{\prime}\right)$ ranged from 0.80 to 0.99 , being highest at Gue and lowest at Nako. An opposite trend was observed in case of Evenness index (E1) values which were recorded to be higher at Nako (0.80) as compared to Chango (0.74) and Gue (0.70). Higher value of Simpson's index of dominance (D) was recorded at Chango (0.46) and almost similar at Nako (0.40) and Gue (0.41). However, value of Margalef's index for richness was higher at Chango (1.13) followed by Gue (0.54) and Nako (0.35).
High values of H' would be representative of more diverse communities. Interestingly, it is evident from the present study that diversity is high in Gue than Chango and Nako, suggesting the presence of a greater number of microbial species at Gue, though microorganisms were not evenly distributed as evenness value was comparatively low. A little variation in the dominance (D) was observed for all the three locations, thereby indicating that all groups of microorganisms dominate almost equally at all the locations.

However, richness was higher in Chango as compared to Nako and Gue. The observed differences in microbial diversity at different locations may reflect variation in the presence of carbon substrates as well as differential use of the substrates by microorganisms. These results are in accordance with the report of Tam et al., (2001). According to Staddon et al., (1997) and Pianka (1966), several factors are known to influence biodiversity viz. the age of a particular area for species colonization, spatial heterogeneity, competition, predation, climatic variability, productivity and disturbance.

As one of the pioneering studies on microbial biodiversity associated with the rhizosphere of Arnebia euchroma - a critically endangered plant, our research illustrates that the rhizosphere of this plant harbors a great deal of microbial diversity which might have significant impact in the perpetuation of this valuable medicinal plant under prevailing harsh climatic conditions in these areas under investigation. Therefore, further research is recommended to better understand the functional diversity of rhizospheric microbial communities as well as their role in conservation and propagation of this plant. Research and scientific data not only determines the importance of biodiversity conservation programmes but also helps in formulating better development intercessions. 


\section{Acknowledgement}

The authors gratefully acknowledge the financial support provided by Gobind Ballabh Pant Institute of Himalayan Environment and Development under National Mission on Himalayan Studies (NMHS), Kosi- Katarmal, Almora - Uttrakhand (India). The soil analysis was performed in the department of Soil Science and water Management, Dr. Y.S. Parmar University of Horticulture and Forestry, Nauni- Solan (HP).

\section{References}

Alluri, V.K., Tayi, V., Rao, N., Sundararaju, D., Mulabagal, V., Hsin-Sheng, T. and Gottumukkaka, S.V. 2005. Assessment of Bioactivity of Indian Medicinal Plants Using Brine Shrimp (Artemiasalina) Lethality. Int. J. Appl. Sci. Eng. 3:125134.

Aswa, B. S., and Mehrotra, B. N. 1994. Flora of Lahaul-Spiti. a cold desert in North West Himalaya,Bishen Singh Mehendra Pal Singh, Dehra Dun, India, 1994.

Bafana, A., and Lohiya, R. 2013. Diversity and metabolic potential of culturable rootassociated bacteria from Origanumvulgare in sub-Himalayan region. World J. Microbiol. Biotechnol. 29: 63-74.

Bednarek, P., Kwon, C. and Schulze, L. P. 2010. Not a peripheral issue: secretion in plant- microbe interactions. Current Opinion of Plant Biology. 13: 378-87.

Berendsen, R. L., Pieterse, C. M. J. and Bakker, P.A.H.M. 2012 The rhizosphere microbiome and plant health. Trends in Plant. Science. 17(8): 1360-1385.

Berg, G., and Smalla, K. 2009. Plant species and soil type cooperatively shape the structure and function of microbial communities in the rhizosphere. FEMS Microbiol. Ecol. 68: 1-13.

Bewket, W., and Steroosnijder, L. 2003. Effects of agro-ecological land succession on soil properties in the Chemoga watershed,
Blue Nile Basin. Ethiopia Geoderma. 111: 85-98.

Bhadrecha, P., Kumar, V. and Kumar, M. 2017. Medicinal Plant Growing under Suboptimal conditions in trans-Himalaya region at High Altitude. Defence Life Science Journal. 2: 37-45.

Crowe, J. H., Hoekstra, F.A. and Crowe, L.M. 1992. Anhydrobiosis. Annual Review of Physiology. 54: 579-599.

Dhyani, P. P., and Kala, C. P. 2005. Current research on medicinal plants: five lesser known but valuable aspects. Current. Science. 88: 335.

Fierer, N., Bradford, M. A. and Jackson, R. B. 2007. Toward an ecological classification of soil bacteria. Ecology. 88: 1354-1364.

Finlay, B. J., 2002. Global dispersal of freeliving microbial eukaryote species. Science. 296:1061-1063.

Gaiero, J. R., Mccall, C. A., Thompson, K. A., Day, N. J., Best, A. S. and Dunfield, K.E. 2013. Inside the root microbiome: Bacterial root endophytes and plant growth promotion. American Journal of Botany. 100: 1738-1750.

Gautam, A. K., Bhatia, M. K. and Bhadauria, R. 2011. Diversity and Usage custom of plants of South Western Himachal Pradesh, India-Part -1. Journal of Phytology. 3(2): 24-36.

Griffiths, R. I., Thomson, B.C., James, P., Bell, T., Bailey, M. and Whiteley, A.S. 2011. The bacterial biogeography of British soils. Environmental Microbiology. 13: 1642-1654.

Hadar, Y., and Papadopoulou, K. K. 2012. Suppressive composts: Microbial ecology links between abiotic environments and healthy plants. Annual Review of Phytopathology. 50: 133-53.

Hartmann, A., Rothballer, M., Schmid, M. and Hiltner, L. 2007. A pioneer in rhizosphere microbial ecology and soil Bacteriology Research. Plant Soil. 312: 7-14.

Hiltner, L., 1904. Uberneuere Erfahrungen und Probleme auf dem Gebietder J.J., Bodenbakteriologie und unterbesonderer Berücksichtigung der Gründüngung und 
BrachteArbeiten der Deutschen Landwirtsch aftlichen Gesellschaft. 98: 5978.

Hinsinger, P., Bengough, A., Vetterlein, D. and Young, I. M. 2009. Rhizosphere: biophysics, biogeochemistry and ecological relevance. Plant Soil. 321: 117-152.

Jackson, M. L., 1967. Soil Chemical Analysis. Prentice Hall of India Pvt Ltd. New Delhi.

Joshi, N. K., Biddinger, D. and Rajotte, E. G. 2011. A survey of apple pollination practices, knowledge and attitudes of fruit growers in Pennsylvania, in 10th International Pollination Symposium (Puebla).

Joshi, P., and Bhatt, A. B. 2011. Diversity and function of plant growth promoting rhizobacteria associated with wheat rhizosphere in North Himalayan region. Int. J. Environ. Sci. 1(6): 1135-1143.

Kala, C. P., 2000. Status and conservation of rare and endangered medicinal plants in the Indian trans-Himalaya. Biological Conservation. 93: 371-379.

Kala, C. P., 2004. Indigenous uses, population density, and conservation of threatened medicinal plants in protected areas of the Indian Himalayas. Conservation Biology. 19(2): 368-378.

Kala, C.P., 1985. Indigenous uses, population density, and conservation of threatened medicinal Campbell R. Plant Microbiology, Baltimore Edward Amold Pp.191.

Karthikeyan, B., Abdul, J. C., Lakshmanan, G. M. A. and Deiveekasundarama, M. 2008. Studies on rhizosphere microbial diversity of some commercially important medicinal plants. Colloids Surf B. Biointerfaces. 62:143-145.

Kloepper, J. W., and Schroth, M. N. 1978. Plant growthpromoting rhizobacteria on radishes. In: Proceeding of the 4th International Conference on Plant PathogenicBacteria. Vol. 2, (pp. 879882) Station de Pathologie Vegetaleet Phytobacteriologie, INRA, Angers,
France

Koeberl, M., Schmidt, R., Ramadan, E.M., Bauer, R. and Berg, G. 2013. Themicrobiome of medicinal plants: diversity and importance for plant growth, quality and health. Front. Microbiol. 4: 400.

Kumar, B. S., Dharmatti, P. R. and Channal, H. T. 2012. Effect of organic cultivation of papaya on yield, economics and soil nutrient status Karnataka. Journal of Agricultural Sciences. 25: 488-492.

Lauber, C.L., Hamady, M., Knight, R. and Fierer, N. 2009. Pyrosequencing-based assessment of soil $\mathrm{pH}$ as a predictor of soil bacterial community structure at the continental scale. Appl. Environ. Microbiol. 75: 5111-5120.

Lindsay, W. L., and Norvell, W. A. 1978. Development of a DTPA soil test for zinc, iron, manganese and copper. Soil Science Society of American Journal. 42: 421428.

Liu, T., Ma, C., Sui, X., Yang, L., Zu, Y., Zhao, C., Li, C. and Zhang, L. 2012. Preparation of shikonin by hydrolyzing ester derivatives using basic anion ion exchange resin as solid catalyst. Ind. Crops. Pro. 36: 47-53.

Lozupone, C. A., and Knight, R. 2007. Global patterns in bacterial diversity. Proceedings of the National Academy Science of United States of America. 104 (27): 11436-11440.

Ludwig J. A., and Reynolds, J. F. 1988. Statistical Ecology. A primer on methods and computing. John Wiley \& Sons.

Macagnan, D., Reginaldo, S., Jorge, T. R., Souza, D. and Alan, W. V. 2006. Pomella. Isolation of Actinomycetes and Endospore-forming Bacteria from the Cacao Pod Surface and Their Antagonistic Activity against the Witches' Broom and Black Pod Pathogens. Phytoparasitica. 34(2): 122-132.

Madigan, M. T., Martinko, J. M., Dunlap, P. V. and Clark, D. P. 2008. Brock Biology of Microorganisms. 12 $2^{\text {th }}$ edition, Benjamin Cummings Pp. 1160-1168. 
Madigan, M. T., Martinko, J. M., Dunlap, P. V. and Clark, D. P. 2009. Brock Biology of Microorganisms, $12^{\text {th }}$ ed., Pearson Education Inc., San Francisco Pp. 673703.

Manjkhola, S., Dhar, U. and Rawal, R. S. 2005. Phenology and biology of Arnebiabenthamii: A critically endangered medicinal plant of the Himalaya. Proc. Indian. Nat. Sci. Acad. 75: 283-287.

Meidute, S., Demoling, F. and Baath, E. 2008. Antagonistic and synergistic effects of fungal and bacterial growth in soil after adding different carbon and nitrogen sources. Soil Biol. Biochem. 10: 1016.

Mendes, L. W., Kuramae, E. E., Navarrete, A. A., Veen, J. A. and Tsai, S. M. 2014. Taxonomical and functional microbial community selection in soybean rhizosphere. ISME. 8: 1577-1587.

Mendes, R., Garbeva, P. and Raaijmakers, J. M. 2013. The rhizosphere microbiome: significance of plant beneficial, plant pathogenic, and human pathogenic microorganisms. FEMS. Microbiol. Rev. 37: 634-663.

Mendes, R., Kruijt, M., Bruijn, I., Dekkers, E., Voort, M. and Schneider, J. H. 2011. Deciphering the rhizosphere microbiome for disease-suppressive bacteria. Science. 332: 1097-1126.

Mendes, R.S., Evangelista, L.R., Thomaz, S.M., Agostinho, A.A. and Gomes, L.C. 2008. A unified index to measure ecological diversity and species rarity. Ecography. 31: 450-456.

Merwin, H. D., and Peach, P. M. 1951. Exchangeability of soil potassium in the sand, slit and clay fractions as influenced by the nature of complementary exchangeable cations. Proccedings Am. Soil. Sci. Soc. 15:125-26.

Nannipieri, P., Ascher, J., Cecvherini, M.T., Landi, L., Pietramellara, G., Renella, G. and Valori, F. 2007. Microbial diversity and microbial activity in the rhizosphere. Cl Suela (Argentina). 25(1): 89-97.

Narula, N., Kothe, E. and Behl, R.K. 2009. Role of root exudates in plant-microbe interactions. J. Appl. Bot. Food. Qual. 82: 122-130.

Nelson, L. M., 2004. Plant growth promoting rhizobacteria (PGPR): Prospects for new inoculants. Online. Crop Management. 10:1094.

Olsen, S. R., Cole, C. V., Whatanable, F. S. and Dean, L. A. 1954. Estimation of available phosphorus by extraction with sodium bicarbonate. US Department of Agriculture Circular No. 939, US Govertment Printing Office, Washington.

Pandey, A. K., Patra, A. K. and Shukla, P. H. 2005. Medicinal plants in Satpura Plateau of Madhya Pradesh Current Status and Future Prospects. Indian Forester. 131: 857-883.

Parmar, D. K., Sharma, V., Sharma, K.D. and Sharma, T. R. 1999. Micronutrient status of vegetable growing pockets in cold desert area of Himachal Pradesh. Journal of the Indian Society of Soil Science. 47: 280-283.

Parveen, K., Suneel S., Sharma, S. and Rajpal, S.D. 2012. Citrus decline in relation to soil-tion to soil-plant nutritional status $-\mathrm{A}$ review. Agri. Reviews. 33: 62-69.

Philippot, L., Raaijmakers, J. M., Lemanceau, P., van der Putten, W. H. 2013. Going back to the roots: the microbial ecology of the rhizosphere. Nat. Rev. Microbiol.11: 789-799.

Pianka, E. R., 1966. Latitudinal gradients in species diversity: a review of concepts. American. Naturalist. 100: 33-46.

Polunin, O., and Stainton, A. 2005. Flowers of the Himalaya, Oxford University Press, New Delhi, India plants in protected areas of the Indian Himalaya. Conservation Biology. 19: 368-378.

Qi, X., Wang, E., Xing, M., Zhao, W. and Chen, X. 2012. Rhizosphere and nonrhizosphere bacterial community composition of the wild medicinal plant Rumexpatientia. World. J. Microbiol. Biotechnol, 28: 2257-2265.

Raina, J. N., Chaudhary, S. K. and Bhandari, A. R. 2003. Status and chemical fractions of 
zinc in apple orchards of Himachal Pradesh. J. Indian. Soc. Soil. Sci. 51: 161168.

Rout, M. E., and Southworth, D. 2013. The root microbiome influences scales from molecules to ecosystems: the unseen majority. Am. J. Bot.100: 1689-1691.

Russell, N.J., 1990. Cold adaptation of microorganisms. Philosophical Transactions of the Royal Society, London B, 326: 595-611.

Saharan, B. S., and Nehra, V. 2011. Plant growth promoting rhizobacteria: a critical review.Life. Sci. Med. Res. 21: 1-30.

Sharma, P., and Mishra, N. K. 2009. "Diversity, utilization pattern and indigenous use of plants in and around a cement factory in Bilaspur District of Himachal Pradesh Northwestern Himalaya" Biological forum- An International Journal. 1: 7080.

Sharma, S. K., Chunrkar, K. C. and Yadav, C. L. 1998. Medicinal plants used in Ayurveda. National Academy for Ayurveda, New Delhi.

Sharma, V., and Kanwar, B. B. 2010. Copper status and its relation with soil properties in pea growing soils of high hills dry temperate zone of Himachal Pradesh. Indian. J. Agric. Res. 44(1): 32-37.

Sharma, V., and Kanwar, B. B. 2012. Macronutrients availability in Pea growing soils of dry temperate zone of Himachal Pradesh. Agric.Sci. Digest. 32(4) 301- 305.

Shen, C. C., Syu, Wan-Jr., Li, S. Y., Lee, C. H. and Sun, C. M. 2002. Antimicrobial activities of naphthazarins from Arnebia euchroma. Journal of Natural Products. 65: 1857-1862.

Singh, K. J., and Thakur, A. K. 2014. Medicinal Plants of the Shimla hills, Himachal Pradesh: A Survey International. Journal of herbal medicine. 2 (2): 118-127.

Singh, K. N., Lal, B., Chand, G. and Todaria, N. P. 2012. Ecological features and conservation of Arnebia Euchroma. A critically endangered medicinal plant in western Himalaya. International Journal of Conservation Science. 3(3): 189-198.

Staddon, W. J., Duchesne, L. C. and Trevors, J. T. 1997. Microbial diversity and community structure of postdisturbance forest soils as determined by sole-carbonsource-utilization. Microbial.Ecology. 34:125-130.

Subbaiah, B. V., and Asija, G. L. 1956. A rapid procedure for the estimation of available nitrogen in soil. Curr. Sci. 25: 259.

Tam, L., Derry, A. M., Keven, P. G. and Trevors, J. 2001. Functional diversity and community structure of microorganisms in rhizosphere and non-rhizosphere Canadian arctic soils. Biodiversity and Conservation. 10: 1933-1947.

Tandon, V., Bhattarai, N. K. and Karki, M. 2001.Conservation assessment and management plan workshop report on selected medicinal plant species of Nepal., 18-20 January 2001, Pokhara, Nepal In: Medicinal and Aromatic Plants (Eds) Programme in Asia (MAPPA), IDRC and Ministry of Forests and Soil Conservation, Nepal.

Timmusk, S., Paalme, V., Pavlicek, T., Bergquist, J., Vangala, A., Danilas, T. and Nevo, E. 2011. Bacterial Distribution in the Rhizosphere of Wild Barley under Contrasting Microclimates. Plos One. 6(3): $1-7$.

Uniyal, S. K., Awasthi, A. and Rawat, G. S. 2002. Current status and distribution of commercially exploited medicinal and aromatic plants in upper Gori Valley, Kumaon Himalaya, Uttaranchal. Current Science. 82: 1246-1252.

Vedand, D. K., and Tandon, V. 1998. CAMP Report for High Altitude Medicinal Plants of Jammu- Kashmir and Himachal Pradesh, Foundation for Revitalization of Local Health Traditions, Bangalore, India.

Ventorino, V., Chiurazzi, M., Aponte, M., Pepe, O. and Moschetti, G. 2007. Genetic diversity of a natural population of Rhizobium leguminosarumbv. Vicianodulating plants of Viciafaba in the Vesuvianarea. Curr. Microbiol. 55: 512- 
517.

Verma, R. K., and Kapoor, K. S. 2009. Plant Wealth in Cold Deserts: Kinnaur, Himachal Pradesh, 31: 95.

Verma, R. K., and Tewari, V.P. 2016. Some Important Medicinal Plants of Cold Desert Regions of District Kinnaur of Himachal Pradesh State in India: Their Uses and Chemical Ingredients. J. Plant. Chem. and Ecophysiol. 1(2): 1009.

Verma, S. D., 1979. Characteristics and genesis of soils of Himachal Pradesh. Ph.D. Thesis submitted to HPKV Palampur (H.P.)

Walkley, A., and Black, I. A. 1934. An examination of digestion method for determining soil organic matter and a proposed modification of the chromic acid titration method. Soil. Sciences. 37: 29-37.

Wang, W.J., Bai, J.Y., Lui, D.P., Xue, L.M., Zhu, X.Y. 1994. The anti-inflammatory activity of shikonin and its inhibitory effect on leukotriene B4 biosynthesis. Yaoxe Xuebao. 29: 161-165.

Wollum, A. G., 1982. Cultural methods for soil microorganisms. In: Methods of soil analysis, Part II, Chemical and microbiological properties. American Society of Agronomy, Inc Publisher Madison, Wisconsin, USA 781-802.

Wynn-Williams, D. D., and Edwards, H. G. M. 2000. Proximal analysis of regolith habitats and protective biomolecules in situ by laser Raman spectroscopy: overview of terrestrial Antarctic habitats and Mars analogs. Icarus. 144: 486-503.

Yadav, R. L., and Meena, M. C. 2009. Available micronutrient status and their relationship with soil properties of Degana soil series of Rajasthan. Journal of the Indian Society of Soil Science. 57: 90-92.

Yakoob, C., Aslam, A. H., Maqbool, A. and Malik, K. A. 2013. Microbial diversity of the rhizosphere of Kochia (KochiaIndica) growing under saline conditions. Pak. J. Bot. 45 (S1): 59-65.

Yang, H., Hu, J., Long, X., Liu, Z. and Rengel, Z. 2016. Salinity altered root distribution and increased diversity of bacterial communities in the rhizosphere soil of Jerusalem artichoke. Sci. Rep. 6: 20687.

\section{How to cite this article:}

Sunita Devi and Kirti Kaundal. 2017. Assessment of Culturable Microbial Diversity Associated with Arnebia euchroma: A Critically Endangered Plant Growing in Trans-Himalayas of Himachal Pradesh. Int.J.Curr.Microbiol.App.Sci. 6(9): 2953-2968.

doi: https://doi.org/10.20546/ijcmas.2017.609.363 